ORIGINAL PAPER

\title{
The lawn grew too quickly! Perception of rural idyll by Czech amenity migrants
}

\author{
Jan Píša ${ }^{1 凶}$ \\ ${ }^{1}$ Faculty of Social and Economic Studies, Jan Evangelista Purkyně University, Moskevská 54, 40096 Ústí nad Labem, Czechia \\ ¡an.pisa@ujep.cz
}

\begin{abstract}
The arrival of amenity migrants has significant impacts for many rural areas in economic, environmental and social terms. While the causes of relocation from cities to remote rural localities can be generally understood as attempts to change the way of life, the consequences of this phenomenon are relatively diverse. Perception of rural space from the migrant's point of view stems partly from the so-called rural idyll, which shapes the image of the countryside across society, especially through media, tourism and recreation. This study aims to discover links between rural idyll and motivational factors of the Czech amenity migrants. Semi-structured interviews with the Czech amenity migrants have been used in order to uncover the social dimension of the phenomenon of rural idyll. Emphasis has been put both on the genesis of their relationship to the rural environment, but also on the consistency and differences between expectations and the reality of rural life. I identify the key role of tourism and recreation in shaping the initial perception of rural space, whereas the role of media is rather implicit. In the perception of amenity migrants, the initial image of rural space differed only slightly when the physical environment of rural space is considered but a mismatch is found between initial ideas about rural communities and their real experience after moving there.
\end{abstract}

\section{Highlights for public administration, management and planning:}

- Rural municipalities should support the coexistence of incoming urban migrants and long-term rural dwellers in order to avoid conflicts between both groups.

- Rural municipalities can attract amenity migrants by building an image that matches rural idyll (stressing the cohesiveness of their communities, supporting production of local food and handicraft products, restoration or construction of physical infrastructure in a way which respect traditional rural construction style).
Keywords

Amenity migration,

Rural idyll,

Czechia

Received:

05 April 2019

Received in revised form: 16 May 2019

Accepted:

24 May 2019

\section{Introduction}

The industrialization of Western countries, which was most intensive during the 19th and 20th centuries, was characterized by a massive shift of the population from rural areas and their concentration in steadily growing cities (Bryant \& Mitchell 2009). In the last decades, however, urbanrural and rural-urban population movements seem to be relatively balanced (Champion 2011). Growing counterurbanization process could be observed also in the post-socialist period of Czechia history, although it is necessary to emphasize that the in- tensity of migration flows to rural space has been spatially differentiated (Ouředníček \& Šimon 2010). Research approaches to concentration and deconcentration processes are quite heterogeneous, as are the reasons for migration between cities and the countryside. Many scholars argue that rural newcomers including amenity migrants are attracted to rural space by so called rural idyll idealised perception of rural space which stresses the positive characteristics of rural space while neglecting the negative ones (e.g. Short 2006, Woods 2011). Conceptualization of rural idyll was the subject of geographical research especially in the turn of the 1990s and 2000s (summary provides i.e. Bell 
2006 or Short 2006) and research of amenity migration started at the beginning of 1990s. Nevertheless, the combination of both concepts has not been qualitatively explored (quantitatively i.e. Blekesaune et al. 2010) in the scientific literature in the context of the post-socialist Central and Eastern European countries yet (although larger thematic overlaps can be observed in Simon 2014; Sustrová \& Šimon 2012). Both concepts have been developed in the western rural geography, therefore researchers from the Central and Eastern Europe have implemented them with certain delay (i.e. Bartoš et al. 2011; Bartoš \& Kušová 2005; Kopp et al. 2009; Wójcik 2013; Závrská 2016). If amenity migration brings both positive and negative effects to rural areas, it is necessary to research not only its consequences, but also explain the causes, including the role of rural idyll in this movement.

This paper aims to fill this gap and introduces results of research of amenity migrants in Czechia. The key questions addressed in this article are: How the rural idyll of Czech amenity migrants is constituted? What are its key elements? How does this idyll correspond to lived experience of these rural immigrants after moving in rural space? Using information from semi-structured interviews conducted in 14 households of amenity migrants, this article attempts to clarify the role of rural idyll in the counterurbanization process. From the individual point of view, I will focus on the construction of the relationship of amenity migrants to rural space and their attitudes to the rural environment, as well as the interaction between urban migrants and rural communities. Similar research questions are the subject of the study of Šimon (2014), Šustrová \& Šimon (2012), Bernard (2006) and Bartoš et al. $(2009,2011)$, but the specific link between amenity migration and rural idyll is only indirectly analysed.

The following part (Section 2.1) aims to conceptualize the amenity migration process. The section devoted to rural idyll (Section 2.2) suggests the reasons for the relatively stable perception of the image of rural space across the society of developed countries. The process of empirical exploration is described in the Methods (Section 3), while part of the Rural idyll and the reality of rural life (Section 4) offers results and summary of main findings. Discussion and conclusions (Section 5) compare results with other studies and briefly summarizes the key aspects of the interaction of rural idyll and amenity migrants.

\section{Rural amenity migration and rural idyll}

\subsection{Rural amenity migration}

Amenity migration is defined as "the movement of people based on the draw of natural and / or cultural amenities" (Gosnell \& Abrams 2011). The rural amenity migration is one branch of the counterurbanization processes defined by Berry (1976) as a process of population deconcentration that results in a change from a state of higher population concentration to a lower concentration. In addition to the deconcentration of the population itself, it is also possible to assess the deconcentration of socioeconomic activities and other cultural (in the broadest sense) elements (in more detail i.e. Ouředníček 2000; Šimon 2011; Champion 2001).

The phenomenon of rural amenity migration is partly related to the "back-to-the-land" process of the Western countries in the 1960s and 1970s (Gosnell \& Abrams 2011). In Czechia we can observe a similar trend which started with the second housing development rather during the 1970s (i.e. Bičík 2001; Vágner \& Fialová 2011). The amenity migration can be understood as a voluntary process that is not primarily motivated by economic reasons, but rather as an attempt to improve living standard of the individuals (Moss 2006; Bartoš et al. 2011; Novotná et al. 2013; Chipeniuk 2005). "Better living standard" can be seen as a qualitative assessment of space resulting from subjective views, attitudes and values held by migrants themselves. Preferences in terms of rural locality selection are relatively diverse due to the diversity of understanding of a good place to live. Nevertheless, more peripheral and backward (although rural idyll plays a role in suburbanization as well; Wójcik 2013) rural areas can be viewed as more attractive for amenity migration due to the more natural character of the environment (Bartoš \& Kušová 2005). The assessment of local attractiveness for this type of migration largely corresponds with the potential of rural areas for tourism development. Indeed, tourism and second housing are mentioned by Stewart (2002) as the phases that usually precede permanent relocation to rural space.

Rural areas have two sources essential for development of amenity migration: a high-quality natural environment and a wide range of socio-cultural specifics which are perceived positively (Bijker et al. 2012). Both resources are distributed unevenly and, given their qualitative and subjective perceptions, they can only be assessed indirectly. 
Moss (1994) summarizes general societal factors supporting amenity migration. These factors are based on a change in the attitudes of the whole society and its shift towards a post-materialist way of thinking. Therefore, increasingly more people in developed countries recognize environmental benefits and various socio-cultural specifics of rural areas. The prerequisite for this social change is the relatively high living standard and higher incomes and free time. The high availability of transport and communication technologies in developed countries enables to travel more often even in remote locations (Kopp et al. 2009).

Amenity migrants can be divided into several categories. Due to the focus of this paper, the following two typologies can be considered as relevant. First, the impact and involvement of migrants in rural social and economic networks is indicated by the ways of livelihood classification. Thus, economically active individuals can be divided into those employed in a rural locality and home-workers (often selfemployed) while other migrant groups consist of retired and financially independent rentiers (Bartoš \& Kušová 2005). Other authors (i.e. Steinicke et al. 2012) also identify second home owners although this does not meet the permanent living premise. Second, if we focus on motivations of amenity migrants, we can consider the variety of reasons for rural in-migration. Here, the typical dual distinction of push and pull factors can be used. Push factors are a set of all negatively perceived properties of the city that motivate individuals to leave (noise, pollution, overpopulation, crime, over-dimensional transport). On the other hand, the expected rural benefits that attract individuals (open landscape, natural environment, peace) summarize pull factors (Halliday \& Coombes 1995). The role of attractive rural aspects (contact with nature, peace, freedom) and repulsive city attributes (lack of nature, rush, stress, poor environment) in the decision-making process of Czech counterurbanizers is also mentioned by Bernard (2006), Šustrová \& Šimon (2012) and Kala et al. (2016). After all, the complex perception of rurality is largely based on urban and rural comparisons (Lošták \& Hudečková 2003). Environmental feature is, however, only partial factor influencing the migration decision (Nakagawa 2018), the role of more subjective factors such as very positive perception of rural space labelled as rural idyll might form the migration behaviour (Stockdale 2014).

Local impacts of migrants can be examined within the social, economic and environmental spheres. From an economic point of view, newcomers can help to solve the problem of lack of knowledge, creativity and entrepreneurial talent in the countryside (Gosnell \& Abrams 2009; Stockdale 2006). With the declining importance of labour-intensive agriculture, the need to create jobs in other more progressive sectors goes hand in hand. Particularly in the case of peripheral rural places, the creation of micro and small enterprises by urban newcomers may be very important. Contrary to local firms owned by indigenous people, migrant enterprises focus rather on distant urban markets (often in the cities where they came from) thanks to their knowledge of local market and embedded social networks. The viability of their enterprises is therefore strongly related to the availability of information, communication and transport technologies (Smallbone 2009). However, car dependency is typical not only for entrepreneurial migrants (Šustrová \& Šimon 2012).

Thus, amenity migration is one of the accompanying phenomena of the transformation of rural space whose functions change over time and which transforms from productivist to multifunctional space (Woods 2005). However, as the community of migrants grows, their ability to enforce their own requirements is also increasing which causes class conflicts, exclusion of indigenous people from the community life or even gentrification process (Gosnell \& Abrams 2009). Bernard's (2006) study identifies a wide range of aspects of integration process and stresses different needs of individual counterurbanizers. Social ties are created on the everyday basis of neighbourhood relations rather than on the base of the opinion homogeneity and friendship of migrants and long-term dwellers. Conflicts between the two groups are odfren based on discrepancies in opinions on various environmental issues. Dopitová (2016) considers the existence of regular meeting places (playgrounds, libraries, pubs), social activities (e.g. Children's Day, "witches burning", carnivals, parties) and organizations (sport clubs, gardening club etc.) to be crucial mechanisms for the integration of newcomers.

\subsection{Rural idyll}

Above mentioned conflicts can arise from the clash of various representations of rural defended by newcomers and indigenous inhabitants whereby the newcomers' representation is very often penetrated by aspects which are incompatible with real rural life. Such representations are then called as rural idyll (e. g. Woods 2011, Bell 2006, Short 2006, Bunce 1994).

The perception of rurality gradually changes during the transformation processes of the past decades. 
Understanding of the countryside as a backward space that needs to be modernized has been replaced by productivist approaches linked to the development of agriculture and the pursuit of food selfsufficiency of individual countries. The subsequent post-productivist transition in Western Europe since the end of 1970s is characterized by an increase in the functional diversity of rural space. Transformation of rural landscape and its functions is typical feature of the post-materialist social changes that have been manifested in recent decades, especially within the developed countries (Soares da Silva et al. 2016). Such changes has been launched also by amenity migration when upper and middle class residents move to rural space in order to find an alternative lifestyle (Cortes-Vazquez 2017) - their movement is very often driven by a positive perception of rural space labelled as rural idyll (Bell 2006). Transformation of rural idyll in the Czech context during the last decades was significantly conditioned by the retreat of socialism and following growth of consumption function of countryside at the expense of production function (Hruška 2014a). Pospěch (2014) also mentions the turn to issues of rural preservation, cultural aspects of rural life, different lifestyle and identities within various rural localities. All of those topics are strongly connected with rural idyll.

Rural idyll is one of the most widespread representation of space significantly influencing the perception of rural space (Mosbacher \& Anderson 1999). It is based on the idea of countryside as a place of a simple living in peace and calm which stands in opposition to the bustle and brashness and disregard of a city (Short 2006). The attempt to escape from modernity and the romantic image of the countryside is apparently widespread across society since spatial thinking of human has been penetrated by the urban-rural dichotomy. However, mass interest in related topics emerged as a result of the growing intensity of negatively perceived attributes of urban life in times of fast urbanization and industrialization (Bunce 1994). Thus, the concept of a rural idyll hides a wide range of features related to space, society, and ways of life.

The rural idyll is created on the base of a wide range of perceptions consumed through many channels (media, tourism, food, etc.). Although the forms of rural idyll across regions and nations differ, certain common categories of idyllic rural place can be identified. Bell (2006) defines three main forms of idyllic landscapes: "Farmscape" is made up of artisanal elements of agriculture landscape, "wildscape" means ideas of pre-human and precultural wildness and "adventurescape" describes the ru- ral as a venue for physical activities and adventures. These forms combine romantic and nostalgic ideas about the countryside (natural beauty, simpler way of life, etc.) and project them into the landscape and its inhabitants (people, animals and plants). Once they immigrated to rural areas, migrants' efforts to improve the environment stem from the need to achieve their representation of rural landscape, therefore, they are not usually driven primarily by ecological motivations (Kondo et al. 2012). Table 1 shows the key features of 'idyllic' rural places and practices.

Table 1 Key attributes of rural idyll

\begin{tabular}{lll}
\hline \multirow{4}{*}{ Place } & \multicolumn{1}{c}{$\begin{array}{c}\text { Feature } \\
\text { group }\end{array}$} & \multicolumn{1}{c}{ Examples } \\
\cline { 2 - 3 } & space & $\begin{array}{l}\text { remoteness, isolation, wildness, } \\
\text { free space, clean environment }\end{array}$ \\
\cline { 2 - 3 } & visuals & vistas, nature, architecture \\
\cline { 2 - 3 } & sounds & $\begin{array}{l}\text { quiet, rural soundscape } \\
\text { (animal, bells, stream) }\end{array}$ \\
\cline { 2 - 3 } Practice & tastes & local food, cuisine style \\
\cline { 2 - 3 } & activities & $\begin{array}{l}\text { free space, hiking, sports, } \\
\text { gardening, animal } \\
\text { breeding/watching }\end{array}$ \\
\cline { 2 - 3 } & traditions & $\begin{array}{l}\text { local culture, music, } \\
\text { healthy food, working activity }\end{array}$ \\
\cline { 2 - 3 } & communities & $\begin{array}{l}\text { peace, togetherness, } \\
\text { harmony, safety, friendship }\end{array}$ \\
\cline { 2 - 3 } & lifestyle & simple, rustic, slow, healthy \\
\hline
\end{tabular}

source: own compilation based on Woods (2011), Bell (2006), Bartoš \& Kušová (2005), Moss (1994), Baylina et al. (2016) and Bijker et al. (2012)

Rural idyll represents a set of impressions, opinions and illusions perceived via individuals' value hierarchies (Little \& Austin 1996) related to the rural environment. As such, it can be considered as a social construct. Priorities, understanding of the rurality and individual behaviour in relation to rural space is based not only on personal experience with the rural environment but also on ideas created in interaction with external resources and personal references of other population groups (e.g. women's rurality - Baylina et al. (2016), Tuitjer (2016)). Rural idyll is formed in a mutual relationship between the rural and urban and their different features (Bell 2006) especially from the dominant middle-class perspective (Halfacree 1993). For example, rural areas are understood to be less developed, but more connected with nature (Woods 2011).

Studies focusing on examination of the Czech way of rural (including the concept of rural idyll) are based mainly on the research of the long-term dwellers of rural municipalities and their perception of the rural and urban (Závrská 2016; Haukanes 
2013). While villagers consider some idyllic factors to be relevant in relation to their own everyday life (the possibility of free movement in the nature, community solidarity, healthier lifestyles, safety, greater family cohesiveness), they draw attention to some factors that can be considered as negative or disruptive from the urban lifestyle perspective (permanent work in the house or garden). From this point of view, rural space can be constructed also less idyllically as a place of production and work in opposition to the consumer character of the city (Závrská 2016). However, migrants from cities construct a rural idyll through visual images of the physical environment (nature, own house, free space) and activities (gardening, animal breeding) rather than the social components as cohesiveness of rural communities, 'less hectic' way of life (Bernard 2006; Bartoš et al. 2009; Šustrová \& Šimon 2012).

The perception of rural landscape attributes is the result of many factors including media, tourism, but also a broad spectrum of personal relationships and experiences that affect attitudes. Michael Bunce (1994) describes the formation of rural idylls through the media. On the other hand, rural idyll might be consumed - countryside can be commodified through a wide range of products, including movies, serials (e.g. Chueh \& Lu 2018), TV shows, food (often with respect to local or national character of goods and other characteristics - Duruz (1999)), flat and garden equipment, or tourism services.

Personal experience of rural idyll, or at least contact with it, can be realized through tourism. Tourist offer adapts to the cultural requirements of consumers. The rural idyll constructed via tourism is therefore not compatible with the present cultural milieu of a destination and it may differ significantly from the reality of rural life (Bell 2006). Buttler (1998) analyses urban residents' need to experience the countryside which is daily presented on TV and PC screens. However, a tourist is not only influenced by media and/or popular culture but also through his/her set of knowledge, experience and social, cultural and economic background which form his/her way of rural idyll (Craik 2002). In the tourist destinations of less developed countries, the gap between rural idyll and the reality of rural life is the most visible. The representation of rural areas presented in tourist resorts does not depart from the experience of long-term rural residents, but rather from the ideas and expectations of owners, designers and tourists (Rigg \& Ritchie 2002). From this point of view, certain natural features of such rural areas do not fit in the expectations (rural idyll) of some potential visitors, especially as regards some elements of agricultural production (noise, smell, electric fences, pesticides, insects, etc.). The tourist idyll is also paradoxically disturbed by the excess of tourism itself (Bell 2006). If we come back to amenity migration, initial rural expectations of newcomers (similarly as those by tourists) might be incompatible with real aspects of rural life. For example, the notion of peace and fresh air is typically spoiled by the rush of tourists, forestry and agricultural activity.

\section{Methods}

In order to thoroughly understand how rural idyll influenced the agency of amenity migrants within rural communities, the semi-structured interview method was selected for our research. The specific methodological framework is taken from Hendl (2016), but similar approaches to related topics can be found in many studies (i.e. Carson et al. 2017; Herslund 2012; Munkejord 2017; Dolejš et al. 2016). Following criteria were set for the selection of interview-partners: (1) the place of their permanent residence is a rural locality, (2) the reason for relocating from urban areas corresponds to the definition of amenity migration (relocation is motivated by an attempt to improve the quality of life from the non-economic point of view), (3) migrants who are (self-)employed don't commute to work but works in the place of residence or in another rural locality. Interview partners were searched in northern Bohemia in Czechia (Fig. 1) based on the administrative boundaries of the Ústí nad Labem and Liberec Region and two northernmost districts of the Central Bohemian Region. Although there is a gradual economic transformation the region, it is possible to regard them as belowaverage in terms of regional socio-economic indicators (ČSÚ 2016). At the same time, the case study area has a significant natural potential for examined type of migration (four Protected Landscape Areas České středohoří, Kokořínsko - Máchův kraj, Lužické hory, Labské pískovce and České Švýcarsko National Park) combined with relatively good accessibility from/to main urban areas such as Prague, Ústí nad Labem, Liberec and other cities. The relative heterogeneity of the study area and its potential influence on various kinds of rural idyll is not considered to be an obstacle. The reason for this is the fact that rural idyll of researched amenity migrants is based on a wide range of individual (in)experiences originating both in urban or other rural areas. As such, their ruralities (both before and after the movement in a given rural locality) 


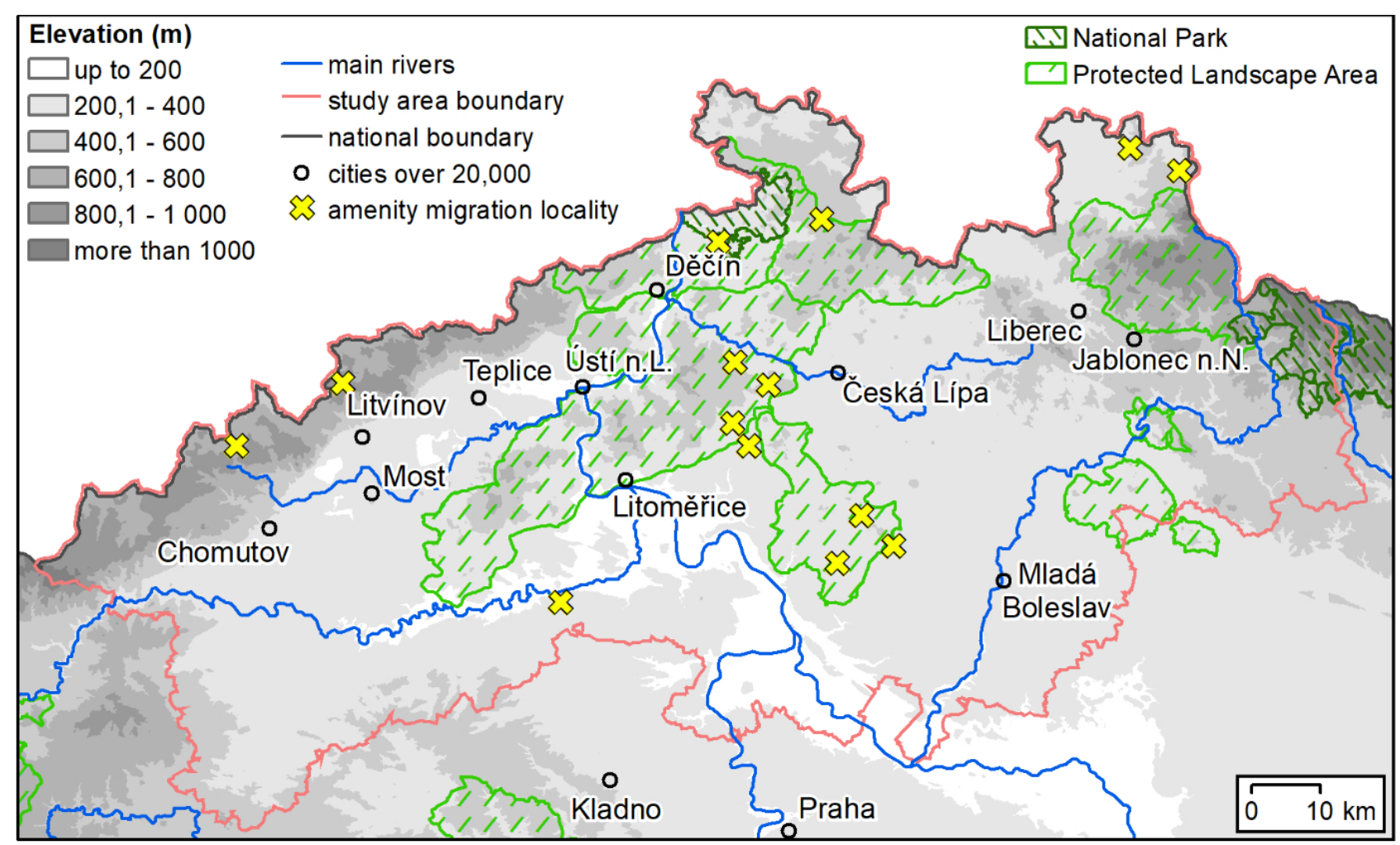

Fig. 1 Study area of northern Bohemia and locations of interview partners. Source: based on ArcČR ${ }^{\circledR} 500$ geodatabase: version 3.3

are not anchored in the physical space as they are part of and create virtual rurality or post-rurality (Cloke 2006 and Murdoch \& Pratt 1993 quoted in Hruška 2014b:590).

Potential interview partners were consulted via email correspondence with representatives of local action groups (LAGs), municipalities, and other local actors, particularly entrepreneurs. As amenity migrants are due to their human, social and financial capital very entrepreneurial and usually form creative class in rural space (Atterton et al. 2012) I analysed also databases of products bearing regional label on the internet. Some other migrants were identified using the snowball method, based on recommendations of other partners. 127 e-mail messages were sent in order to mediate or gain contact with amenity migrants. 35\% of them was replied and recommended 15 amenity migrants. Only one amenity migrant rejected the interview.

During the semi-structured interviews, I used a set of predefined topics relevant for my research. The interviews were recorded with the agreement of the partners using the cell phone's recording application. At the beginning of the interview, the general research topic was introduced, and the interview was opened with the partner narrative. The omitted topics from the following list have been clarified at the request of the researcher.
Recorded conversations were subsequently transcribed and coded according to predetermined topics and research objectives, but also other aspects and new findings gained during the research. The text was analysed according to the methodology of interview analysis based on Hendl (2016). The focus of interviews is based on the study of literature discussing rural idyll and possible reasons for counterurbanization movements as well as its implications for rural localities and communities and migrants themselves:

- formation of rural idyll

- motivations for rural in-migration

- contrast of expectations and reality of rural life

- social life

- change in the quality of life

In addition to these research themes, the general characteristics of migrants were collected (Tab. 2). The quotations of the individual respondents used in the following text are labelled by the case number and letters $\mathrm{F}$ (female) and M (male). 
Table 2 Amenity migrants sample

\begin{tabular}{|c|c|c|c|c|c|}
\hline Case no. & Gender & $\begin{array}{l}\text { Level of } \\
\text { education }\end{array}$ & Hometown (population) & from & $\begin{array}{l}\text { gration } \\
\text { to village (population) }\end{array}$ \\
\hline \multirow{2}{*}{1} & F & tertiary & Praha (1 300 th.) & \multirow{2}{*}{ Praha } & \multirow{2}{*}{$100-200$} \\
\hline & M & secondary & Praha (1 300 th.) & & \\
\hline \multirow{2}{*}{2} & $\mathrm{~F}$ & secondary & Kralupy nad Vltavou (20 th.) & \multirow{2}{*}{ Praha } & \multirow{2}{*}{ up to 50} \\
\hline & M & tertiary & Praha (1 300 th.) & & \\
\hline \multirow{2}{*}{3} & $\mathrm{M}$ & tertiary & Police nad Metují (5 th.) & \multirow{2}{*}{ Praha } & \multirow{2}{*}{$100-200$} \\
\hline & $\mathrm{F}$ & tertiary & Praha (1 300 th.) & & \\
\hline \multirow{2}{*}{4} & $\mathrm{M}$ & secondary & Most (65 th.) & \multirow{2}{*}{ Most } & \multirow{2}{*}{$100-200$} \\
\hline & F & secondary & Litvínov (20 th.) & & \\
\hline \multirow{2}{*}{5} & $\mathrm{~F}$ & tertiary & Pardubice (90 th.) & \multirow{2}{*}{ Ústí nad Labem } & \multirow{2}{*}{$200-300$} \\
\hline & M & tertiary & Most (65 th.) & & \\
\hline \multirow{2}{*}{6} & F & secondary & Chomutov (50 th.) & \multirow{2}{*}{ Chomutov } & \multirow{2}{*}{$50-100$} \\
\hline & M & secondary & Chomutov (50 th.) & & \\
\hline \multirow{2}{*}{7} & $\mathrm{~F}$ & secondary & Praha (1 300 th.) & \multirow{2}{*}{ Praha } & \multirow{2}{*}{$50-100$} \\
\hline & M & tertiary & Praha (1 300 th.) & & \\
\hline \multirow{2}{*}{8} & $\mathrm{~F}$ & secondary & Praha (1 300 th.) & \multirow{2}{*}{ Praha } & \multirow{2}{*}{ up to 50} \\
\hline & M & secondary & Praha (1 300 th.) & & \\
\hline \multirow{2}{*}{9} & $\mathrm{M}$ & secondary & Děčín (50 th.) & \multirow{2}{*}{ Děčín } & \multirow{2}{*}{$600-700$} \\
\hline & F & secondary & Děčín (50 th.) & & \\
\hline \multirow{2}{*}{10} & $\mathrm{M}$ & secondary & village (100) & \multirow{2}{*}{ Praha } & \multirow{2}{*}{ up to 50} \\
\hline & $\mathrm{F}$ & secondary & Praha (1 300 th.) & & \\
\hline \multirow{2}{*}{11} & $\mathrm{M}$ & secondary & Praha (1 300 th.) & \multirow{2}{*}{ Praha } & \multirow{2}{*}{$600-700$} \\
\hline & $\mathrm{F}$ & tertiary & Praha (1 300 th.) & & \\
\hline 12 & F & tertiary & Liberec (surrounding, 100 th.) & Liberec & up to 50 \\
\hline 13 & $\mathrm{~F}$ & secondary & Děčín (50 th.) & & $300-400$ \\
\hline 13 & M & secondary & České Velenice (3.5 th.) & Ceské Velenice & $300-400$ \\
\hline 14 & $\mathrm{M}$ & secondary & Ústí nad Labem (90 th.) & Ústí nad Labem & $100-200$ \\
\hline
\end{tabular}

source: ČSÚ 2016, own interviews

\section{Rural idyll and the reality of rural life}

\subsection{Formation of rural idyll}

Perception of rural space and life is shaped by experience of individuals. From the interviews, it is possible to observe a strong connection between rural expectations and past experience of migrants very often tied to temporary stays in rural space - tourist activities (family trips, holidays), second home and recreation (or stays in grandparents' rural house) or everyday urban connection with certain elements of nature (garden, proximity to nature in the city) during childhood and youth.

"The only big motive was that I spent a year in New Zealand, where I was out of big cities and I just liked that life. So, I decided to implement it here in Czechia as well." (11F)

Other migrants see rural life more comprehensively thanks to their past residential experience in rural space. Their rural perception is, due to more objective experiences, much more focused on everyday activities, not only on the physical environment. Their attitudes to the countryside cannot be seen as categorically positive but purely negative claims only rarely occurred.

"Well, I had experience with the countryside through my grandparents, but it was rather negative. I know the countryside through dirty yards with lots of work. Actually, it's working all the time, right. I didn't experience my grandfather doing anything else than working in the barn or in the field." (7F)

"I'm undemanding. I wasn't a great idealist. I had a family house before. I knew of course that there would be more work with that house. That you have to save money to do some repairs. It has to be taken into account that there is no gas, so we use coal for heating. So, you just need to save on coal and things like that. But I knew that. And I also knew that people are simply different here in the village. Or that there are fewer services." (5M) 
Only one of the surveyed migrants explicitly mentioned the partial influence of literature (book about goat breeding) on own rurality perception. Nevertheless, it can be assumed that the importance of different types of media is crucial to shaping rural idyll across society. The most influencing factors constructing the relationship of examined migrants to rural areas are summarized in Tab. 3. The primary rural experiences are important for its subsequent perception and expectations from rural space.

The difference in attitudes of individual migrants towards the rurality is described in the following quotation, which shows a split of opinion even on the household scale:

"I just grew up in a small town like I said. It has about seven thousand inhabitants, but it is simply a city with everything. It's very old. ... But for my wife born in Praha, it is simply a total village of course. (...) And maybe in such a town I think she wouldn't even want to live. And it is just paradoxical that we got into a village with 150 inhabitants, which is for me like total backwoods. This place is totally backwoods. Absolutely brutal." (3M)

Although the idyllic perception of rural space is a product of both collective and subjective attitudes, it is only rarely the only one condition for urban to rural movement. In general, the motivation leading to migration can be understood as an effort to find a different lifestyle and environment. The need to move from urban to rural place is the result of a combination of push and pull factors. However, by many aspects it is not possible to determine precisely which factor has decisive power, as respondents use relative urban-rural comparisons. For example, there is a noisy city - quiet rural assessment where it is impossible to determine whether the push or pull factor is dominant and contributes to rural migration.

"We were attracted to do something completely different than our parents. We didn't want to work in a transnational corporation. We certainly knew we don't want this. The husband was enticed by animal breeding. I'd say it were very romantic ideas. That we'll start something completely from the beginning and we can change it according to our imagination. But it is not like this. It changes us." (8F)

\subsection{Imagination and the reality of rural life}

Since the original idea of rural life is mainly constructed through images of the natural environment, only in minimum of cases a clear mismatch between expectation and real rural life can be observed. Some respondents initially favoured according to them more attractive rural regions than the often negatively assessed region of northern Bohemia (from the perspective of many respondents, their dream region was rather southern Bohemia). Peace and silence in rural areas were mentioned by most of the respondents among the characteristics they found appealing. However, their expectations in some cases were not met.

"It is a disadvantage that everybody uses the lawn mower here. We have a manual mower here or a scythe. Then when the vehicles go out from the cowshed. That's very noisy, and when those people use those mowers excessively, they totally piss me off. For example, we have an electric saw that can't be heard. A chainsaw rattles over few hundred meters. That bothers me that there is no thoughtfulness here. On Sunday at twelve our neighbour starts to mown or cut something... So that noise bothers me." (12F)

Although the natural environment is predominant in the rural idyll of many respondents, the issue of coexistence with the community is in some cases a subject of unfulfilled expectations. Differences in the way of life of migrants and long-term dwellers seem to be insurmountable, but over time they transform to mutual tolerance or ignorance.

Table 3 Sources of relation to countryside by amenity migrants

\begin{tabular}{|c|c|c|c|c|c|c|}
\hline Experience & \multicolumn{3}{|c|}{ direct } & \multicolumn{2}{|c|}{ occasional } & mediated \\
\hline Source & $\begin{array}{l}\text { rural permanent } \\
\text { housing }\end{array}$ & $\begin{array}{l}\text { stays at rural } \\
\text { residents }\end{array}$ & $\begin{array}{l}\text { second } \\
\text { housing }\end{array}$ & tourism & $\begin{array}{l}\text { proximity } \\
\text { of the nature } \\
\text { within the city }\end{array}$ & $\begin{array}{l}\text { partner's inducement, } \\
\text { the media, } \\
\text { an unspecified desire }\end{array}$ \\
\hline Case & $\begin{array}{l}5 \mathrm{M}, 6 \mathrm{~F}, 10 \mathrm{~F} \\
13 \mathrm{M}, 13 \mathrm{~F}\end{array}$ & $\begin{array}{l}4 \mathrm{~F}, 7 \mathrm{~F}, 9 \mathrm{~F} \\
14 \mathrm{~F}\end{array}$ & $\begin{array}{l}1 \mathrm{M}, 2 \mathrm{~F}, 4 \mathrm{M}, \\
4 \mathrm{~F}, 5 \mathrm{M}, 5 \mathrm{~F}, \\
8 \mathrm{M}, 8 \mathrm{~F}, 9 \mathrm{M}, \\
9 \mathrm{~F}, 10 \mathrm{M}, 10 \mathrm{~F}\end{array}$ & $\begin{array}{l}1 \mathrm{~F}, 2 \mathrm{~F}, 3 \mathrm{M}, \\
3 \mathrm{~F}, 7 \mathrm{M}, 7 \mathrm{~F} \\
8 \mathrm{M}, 8 \mathrm{~F}, 10 \mathrm{~F} \\
11 \mathrm{~F}, 12 \mathrm{~F}\end{array}$ & $1 \mathrm{~F}, 3 \mathrm{M}, 12 \mathrm{~F}$ & $\begin{array}{l}2 \mathrm{M}, 3 \mathrm{~F}, 4 \mathrm{M} \\
6 \mathrm{M}, 8 \mathrm{M}, 9 \mathrm{~F} \\
10 \mathrm{~F}, 14 \mathrm{M}\end{array}$ \\
\hline
\end{tabular}

source:own interviews 
"I was looking forward to those nice people from the countryside very much, as they were all very good and nice. Because we are nice, so they will be nice to us too. So, I got a bit of a shower and just after two years I really recovered of that because I couldn't believe it and it was so sad for me. Now I have absorbed in myself... It's no more painful. But I have to say that it was really annoying. That I was really sorry for it." (10F)

Most often, however, there was a contrast between rural imagined as a space for relaxation and rural as a space of everyday work. Despite practising many leisure activities in nature such as hiking, breeding domestic animals (mostly dogs, sometimes even livestock), mushrooming and gardening before moving to the rural locality, they were not aware of the amount and complexity of the physical work related to the maintenance and renovation of own house and garden. "It has more aspects. You think it will be all simple. For example, work around that house. I had naive ideas about the garden, right. I thought it would be perfectly cool and easy to have a beautiful garden. It was perhaps naive. The lawn grew too quickly. More than I expected. (...) Then it is keeping fire in the stove and doing this annual work during the winter. But we made it quite comfortable here." $5 \mathrm{~F}$

On the other hand, the intensive physical activity helped to improved one respondents' health status as many newcomers stated.

"I' $m$ the healthiest I've ever been in my life. I think it's also because the fact that physical work and the greater amount of physical activity is extremely healthy. So, I feel very positively on myself physically. I have plenty of time to enjoy it. Because I ride a horse every day, so I have a lot of time, or at least an hour and a half a day to enjoy it all around." (7F)

Natural features of the countryside are usually consistent with the original ideas of the individual migrants although the choice of the final rural destination may differ from the dream (more idylically perceived southern vs. northern Bohemia). The attitudes of the interviewees towards the physicalgeographic component of the countryside are relatively positive in the comparison with the perception of the socio-economic sphere.

"And then that view. Tell me who's got this kind of cinema from the window? There are such sunsets in summer that you would bow down to the ground. (...) The landscape is fascinating." (7F)

Integration and networking of migrants with local communities can be largely seen as difficult. Characteristics of local communities depend on the population size of a given community, its location and social structure. The inconsistency of local representation of rural of newcomers and long-term rural dwellers is, according to some respondents, caused generally due to a different lifestyle of both groups. Business activities of more entrepreneurial amenity migrants' are perceived as a foreign element and some kind of transfer of the urban lifestyle to the rural community.

"We have always been perceived as some exotics who are doing some nonsense here and who will leave in a while. Now people got used to us." (8F)

Migrants usually perceive this as a sign of envy. In some cases, local political representatives are also involved in local conflicts and defend interests of some local people at the expense of migrants. This fact and the partial support of some local inhabitants make migrants to join local councils. Change in the attitudes of the local community to the activities of amenity migrants is described in the following quotation from the interview:

"Then there was a crane in the first phase and the first roofs were being repaired and suddenly the local people started to melt (...) and said we were good that we repaired it here. ... So, it was nice, they were glad that we actually did the dirty work for them here. For that they didn't have the capacity. Mentally, financially... they simply didn't have it at all. But then it happened that one day we really started brewing beer here and people started coming here and buying it. (...) And suddenly we found out that some people who were very friendly before, behave somewhat strangely. It still didn't come into my mind what was going on. And when this experience repeated for the third time, we realized it was probably envy." (3M)

Other interviewees perceived negative reactions from the local community as a natural and often inexplicable part of rural social communication. Some migrants consider these features, including passivity and slander, as consequences of regional historical development - they stress the expulsion of Germans after the World War II, subsequent re-settlement and socialist era as key reasons for the low regional identity of local people which is reflected in the poor state of local physical infrastructure (houses, public spaces etc.).

"Gossips in the village such as "one lady said" - they really work here well. Yeah, everyone can see in the plate of other people - it doesn't bother me, but it bothers me when some people are clearly lying and distributing it throughout the village." $(1 \mathrm{~F})$

Four young families with children under school age are particularly worried about the quality of local services. In their opinion, although the country- 
side is an ideal environment for the bringing up, the qualitative and quantitative capacity of school and leisure facilities in the village and its surroundings may not be sufficient. Teachers' approach to children and the quality of education are not discussed by these migrants as a result of a real negative experience with primary schooling but due to their assumptions of poor conditions within the institution. Speculations about its quality can lead to alternative forms of teaching or daily commuting to more distant urban school facilities. The use of a rural school is for some parents only an emergency option.

"There is only one school you can choose. It's not just about the school, but I wouldn't want to give my son there. (...) A lot of people in the neighbouring village teach their children at home. Here's one lady who watches over my son when I need to work. She teaches her children at home too. (...) At worst, he'll go to the elementary school in the larger village nearby. But first I will have to ride him there every day before he can commute alone by bus. (...) That's how it is here. But in the worst case, the school is here." $14 \mathrm{~F}$

Many amenity migrants do actively engage in rural life and cultural events. However, conflicts between newcomers and local people can be observed here. While the activities initiated by migrants themselves are regarded as unauthentic by the locals, the traditional rural festivals (i.e. balls) are referred to by many migrants as funny and bizarre. In Czech rural space local pubs usually serve (sometimes as the only one) social hubs or meeting points of rural people. Nevertheless, its visiting is a result of misbalanced gender relations when women-migrants usually express their contempt for the common interest in alcohol drinking.

"So I think maybe there might be less drinking here. That might be better. I think it's too much in those villages. As we have a lot of cultural events here, there is always a barrel of beer. So, it bothers me a little. I don't see it completely as a problem, because these guys have their job, so don't just go to that pub. But I miss a bit more spiritual dimension. (...) But otherwise I think there's too much alcohol in here." (14F)

On the other hand, the absence of meeting places (including pubs), to a large extent, limits the development of social communication and the emergence of mutual ties between newcomers and long-term dwellers.

While the assumptions and ideas of future life in a given rural locality often differ greatly among amenity migrants and depend on the particular sit- uation and experience of each migrant, all respondents consider their decision to move out from the city to be in a good time. Their future visions are more generally associated with rural space but not with a given rural locality where they have relocated. Nevertheless, most of the migrants admit that they will move to the city again when getting old. From this point of view, rural life is considered as too demanding and uncomfortable due to the worse availability of health care.

\section{Discussion and conclusions}

Amenity migration can significantly influence development of rural localities in social, economic and environmental terms, which are intertwined, and one influence each other. Movement to rural areas is partly driven by an idyllic perception of rural space. However, based on this study, the role of rural idyll in the decision-making process of movement from urban to rural place can be only partially clarified. How much idyllic a given perception of rural space is, is determinated by various factors such as direct contact of individuals with the rural environment, including various forms of tourism (in accordance with Buttler 1998). On the other hand, images presented through the media (as describes i.e. Bunce 1994; Chueh \& Lu 2018) were rarely mentioned by our interviewees - amenity migrants, although we can assume that the influence of media is largely subconscious.

When we summarize and classify all elements by which examined migrants construct their representation of rural space before moving there, we find out that most of the constitutive elements relate to the material components of the rural environment (e.g. natural elements, own house, animals, garden) or anticipated leisure activities which migrants were going to practice in their new rural destination. This finding is fully consistent with Šustrová \& Šimon (2012) and Bartoš et al. (2009). Entrepreneurial activities of most (12 of 14 households) migrants often result from the necessity or unwillingness to commute for work on daily basis, but there are also some (five of 14 households) migrants who project the idea of a new working activity into their rural idyll. It is therefore a part of the idea of how they want to live in their new rural destination.

Obligations and worries arising from the nature of rural space were largely neglected in their perception, similarly also interpersonal relations within rural community. This one-sided imagination of rural space is probably caused mainly by the fact 
that their experience with rural space has been largely shaped by tourism, which usually allows the visitor to see only the idyllic side of the countryside (according to Bell 2006, Craik 2002, Rigg \& Ritchie 2002).

Rural expectations arise from the relative comparison of urban and rural (un)experience and push and pull factors of both milieus. To summarise it, the most frequently mentioned attractive characteristics of rural space include close contact with nature, peace, silence, enough free space and the possibility of breeding animals (similarly as Bernard 2006, Kala et al. 2016, Bartoš et al. 2009, 2011). Migrants also consider the rural as a safer place for bringing up children, which also mention Šustrová \& Šimon (2012). An important pull factor is also the romantic idea of rural life itself. On the other hand, push factors are more often mentioned by former residents of small towns and rural places natives, who after moving to large cities suffered from lack of free space and noise during their stay in a larger city. Furthermore, as in the study by Šustrová \& Šimon (2012) urban emigrants often felt fear of crime and perceived negatively traffic congestion. The choice of a specific rural destination depends on previous experience with the places not on the scale of specific municipalities but rather within the wider physicalgeographic regions (i.e. Kokořínsko, or Krušné hory Mt.). The purely pragmatic reason for choosing a concrete location is then the availability of a suitable property.

As Stockdale (2014) argues, understanding rural migration decisions only as a result of the abovedescribed rural idyllic motivation factors would be too simplified. An important role can also be attached to many specific events in the lives of individuals that can act as a break point or catalyst in the decision-making process (leaving a partnership, death in a family, heritage). In each case, there may be many factors causing a change of living place.

The source of the mismatch between expectations and reality of rural life therefore rests not only in the aspects which are contradictory to the own rural idyll but rather in aspects that the migrant didn't imagine. If the negatively perceived features of the city (noise and poor social situation) have contributed to the relocation to rural setting, the occurrence of similar negatives in the village environment may be a source of another stress. In this context, Halliday and Coombes (1995) notes the same stressful factors - rural noises, alcoholism, etc. Unexpected negatives of rural life have a dual character. The first type, due to the expectation of ur- ban comfort even in the rural environment, is linked to the large amount of physical work associated with the maintenance of the house and garden, which are sources of physical and financial exhaustion but also self-fulfilment (similar ambivalence is noted in Šustrová \& Šimon 2012). On the contrary, the immediate non-acceptance of a migrant into the local community is often negatively perceived psychologically. These elements are regarded as surprising, and therefore their negative effects can to some extent be considered ephemeral. The reason for conflicts between long-term residents and newcomers is their different lifestyle and more generally different representation of rural. While local people consider the migrants as exotic and intruders, migrants mention the backwardness and passivity of the second group, which corresponds to Bernard (2006). This mutual discrepancy relates with the fact that most amenity migrants do some entrepreneurial activity. It can significantly influence the results of this research, although it is not possible to determine exactly what is the proportion of individual subcategories (the categories summarize i.e. Bartoš \& Kušová 2005) of amenity migrants in their total number.

The ability to realistically estimate the specifics of rural life is naturally related to the previous experience of individual migrants with rural space. Therefore, respondents with experience of permanent housing in rural space (five individuals in 14 households) do not perceive any discrepancy between their expectations and reality. Yet their need to return to rural space is more perceptible than that of originally urban migrants. The geographic remoteness and very limited facilities of rural locations lead to dependence on transport and communication technologies, which most of the respondents consider as natural because they were used to use cars frequently and similarly also internet and cell phones during their urban life period.

Šustrová \& Šimon (2012) mention lower community cohesion and poorer cultural life in the resettled areas of the former Sudetenland (area which was dominantly populated by German population before the WWII). This assumption cannot be confirmed or refused due to the missing comparative aspect of selected rural localities (all are situated in the Sudetenland). However, even here, there is considerable heterogeneity in the local scale, and it is necessary to warn against overgeneralization. Similarly like in Dopitová (2014), migrants from my study mention the lack of social activities and meeting places in small villages as a barrier of integration to the local community. Moreover, the participation of migrants seems 
to be determined by the pursuit of inclusion rather than by interest in a particular activity.

Despite these mismatches with the rural idyll of amenity migrants, relative satisfaction with the decision to move from urban to rural can be observed across the group of interview partners. Mentioned positives are often contrasted with low levels of comfort, lack of local services and high level of car dependency and physical work. Generally, the overall isolation of rural sites is mentioned as their largest disadvantage. Beside this, the natural component of the countryside is a source of enthusiasm and admiration of all migrants.

\section{Acknowledgement}

I would like to thank the Internal Grant Agency of the Jan Evangelista Purkyně University in Ústí nad Labem for the financial support (Project UJEP-SGS-183-02-05: Podnikatelská migrace z měst na venkov: její význam pro rozvoj venkovských oblastí a reflexe v plánování venkova / Entrepreneurial urban-to-rural migration: its importance for rural development and its reflection in rural development policies).

\section{References}

ArcČR ${ }^{\circledR} 500$ geodatabase: version 3.3. https://www.arcdata.cz/produkty/geograficka-data/arccr-500

Atterton J, Bryden J, Johnson, T G (2012) Rural economic transformation in the UK and US. In: Shucksmith M, Brown D L, Shortall S, Vergunst J, Warner M E (eds.) Rural transformations and rural policies in the US and UK. Routlege, London, pp. 117-137.

Bartoš M, Kušová D, Těšitel, J (2009) Motivation and life style of the Czech amenity migrants (case study). European Countryside 1(3): 164-179.

Bartoš M, Kušová D, Těšitel J, Novotná $\mathrm{M}$, Kopp J, Macháček J, Moss LAG, Glorioso RS (2011) Amenitní migrace do venkovských oblastí České republiky. Lesnická práce, Kostelec nad Černými lesy.

Bartoš M, Kušová D (2005) Amenitní migrace jako specifická forma globální migrace obyvatel a její vliv na kvalitu života. Životne prostredie 39(6): 315-318.

Baylina M, Garcia-Ramon M D, Porto A M, Salamaña I, Villarino M (2016) Women Assess Rurality-A Tailored Rural Idyll. In: Wiest K (ed.) Women and Migration in Rural Europe. Palgrave Macmillan, London, pp. 25-43.

Bell D (2006) Variation on the Rural Idyll. In: Cloke P, Marsden T, Mooney, P (eds) Handbook of Rural Studies. Sage, London, pp. 149-160.

Bernard J (2006) Sociální integrace přistěhovalců z velkoměsta na vesnici v České republice a v Rakousku. Sociologický časopis/Czech Sociological Review 42(4): 741-760.

Berry B J (1976) The counterurbanization process: urban America since 1970. SAGE Publications, Beverly Hills, CA.

Bičík I (2001) Druhé bydlení v Česku. Univerzita Karlova, Praha. Bijker R A, Haartsen T, Strijker, D (2012) Migration to lesspopular rural areas in the Netherlands: Exploring the motivations. Journal of Rural Studies 28(4): 490-498.
Blekesaune A, Haugen M S, Villa M (2010) Dreaming of a smallholding. Sociologia Ruralis 50(3): 225-241.

Bryant C R, Mitchell C J (2009) Counterurbanization. In: Kitchin $\mathrm{R}$, Thrift $\mathrm{N}$ (eds.) International Encyclopedia of Human Geography. Elsever, Amsterdam, pp. 319-324.

Bunce M (1994) The Coutryside ideal: Anglo-American Images of Lanscape. Routledge, London and New York.

Buttler R (1998) Rural recreation and tourism. In: Ilbery B (ed.) The Geography of Rural Change. Longman, Harlow, pp. 221-232.

Carson D A, Carson D B, Eimermann M (2017) International winter tourism entrepreneurs in northern Sweden: understanding migration, lifestyle, and business motivations. Scandinavian Journal of Hospitality and Tourism 18(2): 183-198.

Champion T (2001) Urbanization, Suburbanization, Counterurbanization and Reurbanization. In: Paddison R (ed.) Handbook of Urban Studies. SAGE Publications, London, pp. 143-161.

Chipeniuk R (2005) Planning for rural amenity migration. Plan Canada 45 (1): 15-17.

Chueh H C, Lu Y H (2018) My dream life in a rural world: A nonfiction media representation of rural idyll in Taiwan. Journal of Rural Studies 59: 132-141.

Cloke P (2006) Conceptualizing rurality. In: Cloke P, Marsden T, Mooney P (eds.) Handbook of rural studies. Sage, London, pp. 18-28.

Cortes-Vazquez J A (2017) The end of the idyll? Post-crisis conservation and amenity migration in natural protected areas. Journal of rural studies 51: 115-124.

Craik J (2002) The Culture of Tourism. In: Rojek C, Urry J (eds.) Touring Cultures: Transformations of Travel and Theory. Routledge, London, pp. 114-136.

ČSÚ (2016) Vše o území VDB. https://vdb.czso.cz/vdbvo2/faces/cs/index.jsf? page $=$ profil-uzemi

Dolejš M, Glorius B, Hruška V (2016) Motives and barriers of migration to Saxony: the case of migrating health professionals from Czechia. GeoScape 10(2):62-77.

Dopitová M (2016) Social Engagement and Rural Newcomers. Sociální studia/Social Studies 13(2): 73-91.

Duruz J (1999) Food as nostalgia: Eating the fifties and sixties. Australian Historical Studies 29(113): 231-250.

Gosnell H, Abrams J (2011) Amenity migration: diverse conceptualizations of drivers, socioeconomic dimensions, and emerging challenges. GeoJournal 76(4): 303-322.

Glorioso R S (2000) Amenity migration in the Sumava Bioregion, Czech Republic: Implications for ecological integrity. In: Gode PM, Price MF, Zimmermann FM (eds) Tourism and development in mountain regions, $\mathrm{CABI}$ Publishing, $\mathrm{CAB}$ International, Oxon, UK, pp. 275-295.

Halfacree K (1993) Locality and social representation: space, discourse and alternative definition of the rural. Journal of Rural Studies 9(1): 23-37.

Halliday J, Coombes M (1995) In search of counterurbanisation Some evidence from Devon on the relationship between patterns of migration and motivation. Journal of Rural Studies 11(4): 433-446.

Haukanes H (2013) Belonging, mobility and the future: Representations of space in the life narratives of young rural Czechs. Young 21(2): 193-210. 


\section{sciendo}

Hendl J (2016) Kvalitativní výzkum: základní teorie, metody a aplikace. Portál, Praha.

Herslund L (2012) The Rural Creative Class: Counterurbanisation and Entrepreneurship in the Danish Countryside. Sociologia Ruralis 52(2): 235-255.

Hruška V (2014a) Diferenciace venkovského prostoru na príkladu Moravskoslezského kraje. Doctoral dissertation, Masarykova univerzita, Př́rodovědecká fakulta, Brno.

Hruška V (2014b). Proměny př́stupů ke konceputalizaci venkovského prostoru v rurálních studiích. Sociologický časopis/Czech Sociological Review 50(04): 581-601.

Kala L, Galčanová L, Pelikán V (2016) Residential preferences in the context of voluntary simple lifestyles: What motivates contemporary Czech simplifiers to reside in the countryside? Human Affairs 26(4): 410-421.

Kondo M C, Rivera R, Rullman Jr S (2012) Protecting the idyll but not the environment: Second homes, amenity migration and rural exclusion in Washington State. Landscape and urban planning 106(2): 174-182.

Kopp J, Novotná M, Kušová D (2009) Krajinně-ekologické faktory amenitní migrace obyvatel na př́kladu modelových venkovských krajin České republiky. In: Pucherová Z, Vanková V (eds.) Problémy ochrany a využívania krajiny - teórie, metódy a aplikácie. Združenie Biosféra, Nitra, pp. 219-228.

Labov W (2006) The study of language in its social context. In: Labov W (ed) The Social Stratification of English in New York City. Cambridge University Press, Cambridge, pp. 3า-17.

Little J, Austin P (1996) Women and the rural idyll. Journal of Rural Studies 12(2): 101-111.

Lošták M, Hudečková H (2003) Stabilita a flexibilita v představách o venkově a projekce do venkovského rozvoje. In: Agrární perspektivy XII. Provozně ekonomická fakulta České zemědělské university v Praze, Praha, pp. 755-764.

Mosbacher M, Anderson D (1999) Another country. Social Affairs Unit, London.

Moss L A (1994) Beyond Tourism: The Amenity Migrants. In: Mannermaa M, Inayatullah S, Slaughter R (eds) Coherence and Chaos in our Uncommon Futures-Visions, Means, Actions. Finland Futures Research Centre, Turku, pp. 125-137.

Moss L A (2006) The amenity migrants: Seeking and sustaining mountains and their cultures. CABI, Cambridge.

Munkejord M C (2017) Becoming Spatially Embedded: Findings from a Study on Rural Immigrant Entrepreneurship in Norway. Entrepreneurial Business and Economics Review 5(1): 111-130.

Murdoch J, Pratt A C (1993) Rural studies: modernism, postmodernism and the 'post-rural'. Journal of rural studies,9(4):411-427.

Novotná M, Preis J, Kopp J, Bartoš M (2013) Changes in migration to rural regions in the Czech Republic: Position and perspectives. Moravian Geographical Reports 21(3): 37-54.

Nakagawa Y (2018) Psychological and Behavioral Predictors of Rural In-migration. Rural Sociology 83(1): 24-50.

Ouředníček M (2000). Teorie stádií vývoje měst a diferenciální urbanizace. Geografie 105(4): 361-369.

Pospěch P (2014) Vynalézání venkova v ČR po roce 1989. Centrum pro studium demokracie a kultury, Brno.
Rigg J, Ritchie M (2002) Production, consumption and imagination in rural Thailand. Journal of Rural Studies 18(4): 359-371.

Short B (2006) Idyllic Ruralities. In: Cloke P, Mardsen T, Mooney P (eds.) The Handbook of Rural Studies. SAGE Publishing, London, pp. 133-148.

Smallbone D (2009) Fostering entrepreneurship in rural areas. In: Potter J, Hofer A R (eds) Strengthening entrepreneurship and economic development in East Germany: lessons from local approaches. Organisation for Economic Co-operation and Development, Paris, pp. 164-187.

Soares da Silva D, Figueiredo E, Eusébio C, Carneiro M J (2016) The countryside is worth a thousand words - Portuguese representations on rural areas. Journal of Rural Studies 44: 77-88.

Steinicke E, Čede P, Löffler R (2012) In-migration as a new process in demographic problem areas of the Alps. Ghost towns vs. amenity settlements in the alpine border area between Italy and Slovenia. Erdkunde 66(4): 329-344.

Stewart S I (2002) Amenity Migration. In: Luft K, MacDonald, S (eds) Trends 2000: Shaping the Future, 5th Outdoor Recreation $\&$ Tourism Trends Symposium. Michigan State University Department of Park, Recreation and Tourism Resources, Lansing, MI, pp. 369-378.

Stockdale A (2006) Migration: Pre-requisite for rural economic regeneration? Journal of Rural Studies 22(3): 354-366.

Stockdale A (2014) Unravelling the migration decision-making process: English early retirees moving to rural mid-Wales. Journal of Rural Studies 34: 161-171.

Šimon M (2011) Kontraurbanizace: chaotický koncept? Geografie, 116(3):231-255.

Šimon M. (2014) Exploring Counterurbanisation in a Post-Socialist Context: Case of the Czech Republic. Sociologia ruralis 54(2): 117-142.

Šustrová K, Šimon M (2012). Opuštění městského způsobu života? Analýza vybraných aspektů migrace na venkov. In: Temelová J, Pospíšilová L, Ouředníček M (eds.) Nové sociálně prostorové nerovnosti, lokální rozvoj a kvalita života. Vydavatelství a nakladatelství Aleš Čeněk, Plzeň, pp. 99-121.

Tuitjer G (2016) References to a Rural Idyll in the Attitudes and Self-perceptions of Women in Rural West Germany. In: Wiest K (ed) Women and Migration in Rural Europe. Palgrave Macmillan, London, pp. 44-63.

Vágner J, Fialová D (2011) Druhé bydlení - nejen české specifikum. Geografické rozhledy, 21(1): 8-9.

Valentinov V (2005) The changing role of producer selforganization in the development of transitional agriculture. In: Bremer T (ed) VII World Congress of the International Council for Central and East European Studies. ICCEES, Berlin.

Wójcik M (2013) Territorial identity of countryside residents in the suburban areas of Łódź, Poland. Quaestiones Geographicae 32(2): 69-79.

Woods M (2005) Rural geography: processes, responses, and experiences in rural restructuring. SAGE Publications, Thousand Oaks, CA.

Woods M (2011) Rural. Routledge, London.

Závrská V (2016) Představy o rurálním a představení v rurálním: Sociální konstrukce rurality české vesnice (dissertation thesis). Univerzita Palackého v Olomouci, Olomouc. 